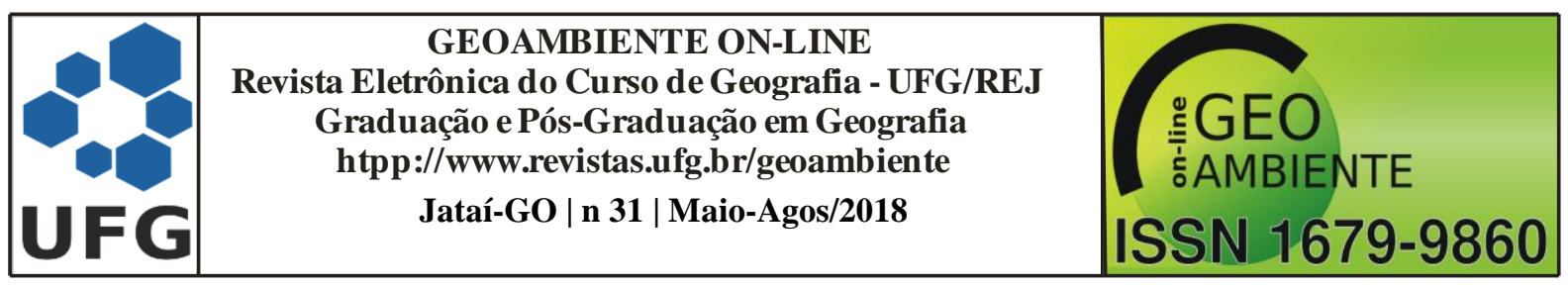

\title{
MORFOPEDOLOGIA, COMPOSIÇÃO FLORÍSTICA E FITOSSOCIOLOGIA DE UMA VEREDA NO SUDOESTE DE GOIÁS
}

\author{
Eduardo Vieira dos Santos ${ }^{1}$, Frederico Augusto Guimarães Guilherme ${ }^{2}$, Gustavo Rodrigues \\ Barbosa Barbosa $^{3}$, Steffan Eduardo Silva Carneiro ${ }^{4}$ \\ (1 - Universidade Federal do Mato Grosso, Doutorando em Geografia - UFG/REJ \\ edugeo2000@yahoo.com.br; 2 - Universidade Federal de Goiás, Professor Doutor do \\ Programa de Pós-Graduação em Geografia e Curso de Biologia; fredericoagg@gmail.com, 3 \\ - Universidade Federal de Goiás, Doutorando em Geografia - UFG/REJ, \\ gus696@gmail.com; 4 - Universidade Federal de Goiás, Mestre em Geografia, \\ steffan.hb88@hotmail.com)
}

Resumo: Veredas são fisionomias singulares no Cerrado brasileiro, constituídas por plantas associadas a solos hidromórficos em vales rasos onde é notória a ocorrência de buritizais. O objetivo desse estudo foi contribuir com o conhecimento morfopedológico, florístico e fitossociológico em uma Vereda no Sudoeste Goiano. Foi feito o mapeamento da hipsometria e de declividade, utilizando-se imagens orbitais SRTM. Foram analisados os parâmetros físicoquímicos dos solos em amostras da camada superficial e subsuperficial em três zonas da Vereda. No levantamento da vegetação foram alocadas 18 parcelas de $50 \mathrm{~m}^{2}$ cada, divididas em dois grupos: zona com presença do buriti (encharcada) e zona sem presença do buriti. Observou-se que a geomorfologia local contribuiu para o surgimento e desenvolvimento da Vereda, que possui solo de elevada acidez e altos teores de areia. Miconia foi o gênero mais rico em espécies e muito abundante em relação ao componente arbustivo. Por outro lado, espécies arbóreas, como Tapirira guianensis e Cecropia pachystachya na zona encharcada, ocorrendo simultaneamente com Mauritia flexuosa, indicaram tendência evolutiva da Vereda estudada. Esse estudo mostrou que avaliações conjuntas de elementos bióticos e abióticos ajudaram a caracterizar a Vereda, reforçando a importância de estudos que integrem vários aspectos da paisagem para melhor conhecer os ecossistemas úmidos.

Palavras-chave:Cerrado. Fitofisionomia de Vereda. Relevo e atributos edáficos.

Artigo recebido para publicação em 01 de Março de 2018

Artigo aprovado para publicação em 19 de Agosto de 2018 


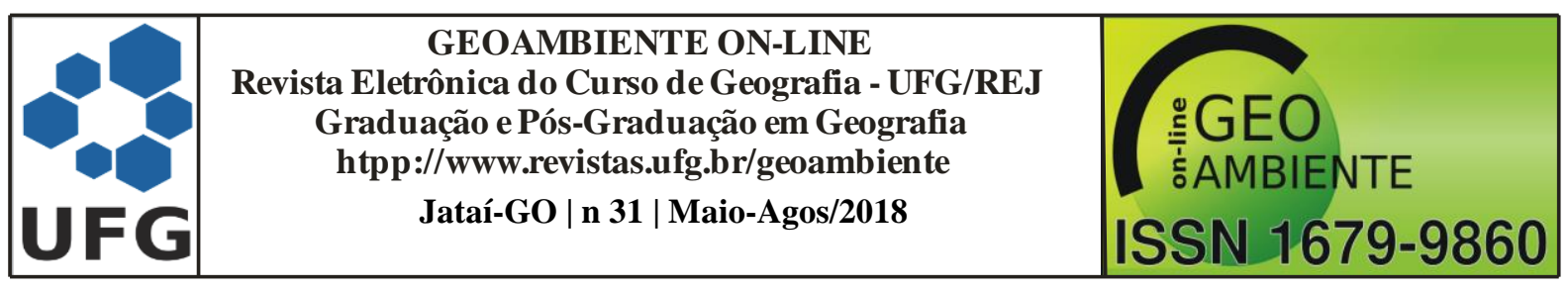

\title{
MORPHOPEDOLOGY, FLORISTIC COMPOSITION AND PHYTOKOCYOLOGY IN VEREDA IN THE SOUTHWEST OF GOIÁS
}

\begin{abstract}
Veredas are singular physiognomies in the Brazilian Cerrado, constituted by plants associated to hydromorphic soils in shallow valleys where the occurrence of palm swamp is notorious. The objective of this study is to contribute with morphopedological, floristic and phytosociological knowledge in a Vereda in Southwest of Goiás state. Hypsometry and slope mapping was done using SRTM orbital images. The physical and chemical parameters of the soils were analyzed in samples of the superficial and subsurface layer in three zones of the Vereda. In the survey of the vegetation, 18 plots of $50 \mathrm{~m}^{2}$ each were allocated, divided into two groups: zone with buriti (flooded) and a zone without buriti. It was observed that local geomorphology contributed to the emergence and development of the Vereda, which has high acidity soil and high levels of sand. Miconia was the richest genus in species and very abundant in relation to the shrub component. On the other hand, arboreal species, such as Tapirira guianensis and Cecropia pachystachya in the flooded zone, occurring simultaneously with Mauritia flexuosa, indicated an evolutionary tendency of the Vereda. This study showed that the joint evaluation of biological and abiotic elements helps to characterize the Vereda, reinforcing the importance of studies that integrate several of the landscape to better know the wetland ecosystems.
\end{abstract}

Keywords: Cerrado. Phytophysiognomy of Vereda. Relief and edaphic attributes.

\section{MORFOPEDOLOGÍA, COMPOSICIÓN FLORÍSTICA Y FITOSOCIOLOGÍA EN VEREDA EN EL SUROESTE DE GOIÁS}

Resumen: Veredas son fisonomías singulares en el Cerrado brasileño, constituidas por plantas asociadas a suelos hidromórficos en valles rasos donde es notoria la ocurrencia de palmares. El objetivo de este estudio fue contribuir con el conocimiento morfopedológico, florístico y fitosociológico en una Vereda en el Suroeste goiano. Fue hecho el mapeo de la hipsometría y de la declividad, utilizando imágenes orbital SRTM. Se analizaron los parámetros físico-químicos de los suelos en muestras de la capa superficial y subsuperficial en tres zonas de la Vereda. En el levantamiento de la vegetación fueron reservadas 18 parcelas de $50 \mathrm{~m}^{2}$ cada una, divididas en dos grupos: zona con presencia del buriti (empapada) y zona sin presencia del buriti. Se observó que la geomorfología local contribuyó al surgimiento y desarrollo de la Vereda, que posee suelo de elevada acidez y altos tenores de 


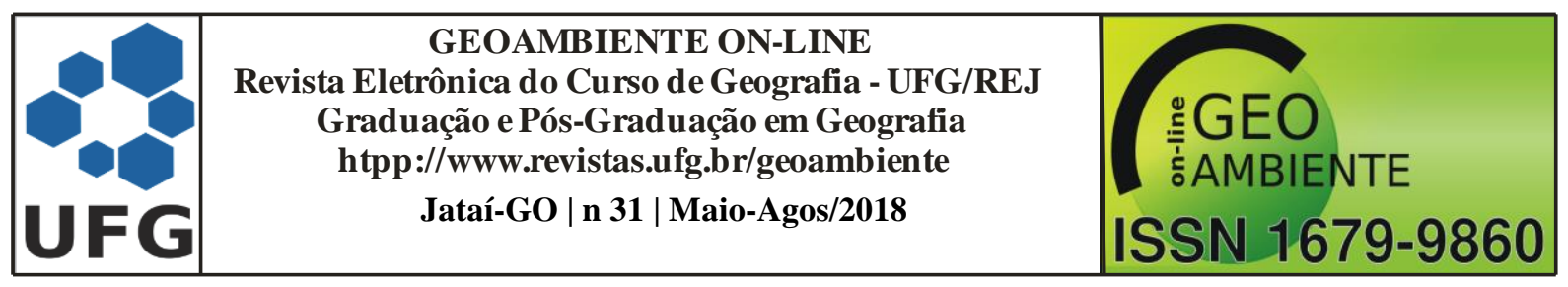

arena. Miconia fue el género más rico en especies y muy abundante en relación al componente arbustivo. Por otro lado, especies arbóreas, como Tapirira guianensis y Cecropia pachystachya en la zona empapada, ocurriendo simultáneamente con Mauritia flexuosa, indicaron tendencia evolutiva de la Vereda estudiada. Este estudio mostró que evaluaciones conjuntas de elementos bióticos y abióticos ayudaron a caracterizar la vereda, reforzando la importancia de estudios que integren varios aspectos del paisaje para mejor conocer los ecosistemas húmedos.

Palabras clave: Cerrado. Fitofisionomía de Vereda. Relieve y atributos edáficos.

\section{INTRODUÇÃO}

O Cerrado é considerado um mosaico de formações vegetais que variam desde campos abertos até formações densas de florestas (EITEN, 1972; RIBEIRO, WALTER, 2008). Uma dessas fisionomias são as Veredas; áreas úmidas que desempenham um papel vital para a manutenção de processos ecológicos e são locais de alto endemismo, pois selecionam espécies adaptadas a sobrevirem nessa paisagem singular (MELO, 2008). Essas podem ser diferenciadas a partir do tipo de vegetação, regime hidrológico e do tipo de solo, sendo que, no Cerrado, a vegetação hidrofítica aliada aos solos hidromórficos, são utilizados para a identificação dessas áreas (DE-CAMPOS et al., 2013).

Conceitualmente, as Veredas são espaços brejosos ou encharcados, que contêm nascentes ou cabeceiras de cursos d'água, onde há ocorrência de solos hidromórficos, caracterizados predominantemente por populações de buritis (Mauritia flexuosa L.f.), além de outras espécies e formas de vegetação típica (FERREIRA, 2005/2006). Embora a presença do buriti seja característica marcante da Vereda, em fases mais evoluídas podem ser encontradas junto aos buritis, ilhas de vegetação lenhosa (CARVALHO, 1991).

A Vereda está relacionada à alta umidade do solo, associada ao afloramento de lençol aquífero ou a borda de curso d'água. Desse modo, em geral estão presentes em vales com baixa declividade favorecendo as condições de má drenagem. Considerando as características geomorfológicas das Veredas como importantes para o maior conhecimento desse ambiente foram desenvolvidos alguns estudos (BOAVENTURA, 1978; 1988; FERREIRA, 2005/2006). Outra característica peculiar às Veredas é o solo, geralmente, com alta umidade e elevados teores de matéria orgânica que tende a aumentar nas porções inferiores. Estudos sobre as 


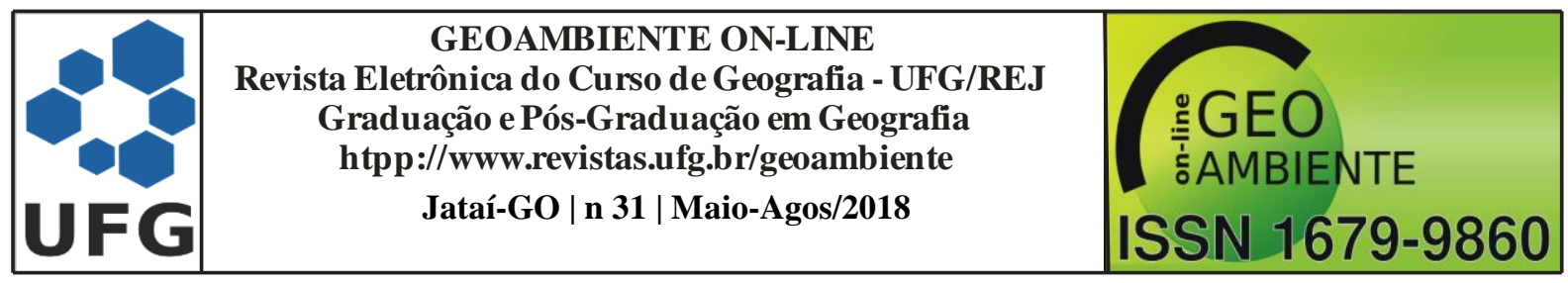

características dos solos em Veredas têm sido desenvolvidos nos últimos anos (RAMOS, 2000; 2004; FERREIRA, 2003; RAMOS et al., 2006; BISPO, 2010; PASSOS et al., 2015).

Estudos florísticos e fitossociológicos em Veredas foram realizados por Guimarães, Araújo e Corrêia (2002), Araújo et al. (2002), Ramos (2004), Oliveira (2005) no Triângulo Mineiro; Bahia et al. (2009), Fagundes e Ferreira (2016), Ávila et al. (2016) no norte de Minas Gerais; Reis (2008) no oeste da Bahia; Moreira, Pott e Pott (2009), Moreira (2015) no Estado de Mato Grosso do Sul; Ferreira (2008), Resende (2010) no Estado de Goiás; Silva et al. (2016) no Distrito Federal. Mesmo assim, devido às peculiaridades encontradas nesses ambientes, ao longo de sua ampla faixa de distribuição na América do Sul, pouco se conhece sobre sua biota e os aspectos físicos que originaram e mantêm esses importantes ecossistemas.

A Vereda apresenta importância por ser local de nascente de vários cursos de água, constitui um refúgio para a fauna e a flora (biota como um todo), é local de dessedentação dos animais do Cerrado, mantém inter-relações com outros subsistemas e exerce o papel de corredores ecológicos naturais, permitindo o fluxo biótico das populações de plantas e animais do Cerrado (CASTRO, 1980). É fonte de suprimentos de alimentos e sítios de reprodução para diversas espécies (GUIMARÃES; ARAÚJO; CORRÊA, 2002). Também é importante para a conservação dos solos e da elevada biodiversidade existente, especialmente do componente herbáceo-graminoso, além de, em muitos casos, ser responsável pela perenização dos cursos de água, visto que atuam como bacias coletoras (AGUIAR; CAMARGO, 2004; RAMOS, 2006). Pode-se destacar, também, o papel social exercido pelas mesmas, para pequenas comunidades de agricultores que exploram sustentavelmente o buriti, para diversas finalidades (FONSECA; SILVA, 1998).

Diante da intensa ocupação recente do Cerrado, da importância, da fragilidade e da necessidade de se conhecer melhor a Vereda para se propor estratégias de conservação, o presente trabalho tem por objetivo contribuir com o conhecimento geomorfológico, pedológico, florístico e fitossociológico, em uma Vereda no Sudoeste Goiano.

\section{MATERIAL E MÉTODOS}

Área de estudo

O estudo foi realizado em uma Vereda situada logo após o front da cuesta do Caiapó, porção sul do município de Caiapônia (GO), integrante da Microrregião Sudoeste de Goiás (Figura 1). A Vereda está inserida na borda nordeste da Bacia Sedimentar do Paraná ou 


\begin{tabular}{|c|c|c|}
\hline & $\begin{array}{c}\text { GEOAMBIENTE ON-LINE } \\
\text { Revista Eletrônica do Curso de Geografia - UFG/REJ } \\
\text { Graduação e Pós-Graduação em Geografia } \\
\text { htpp://www.revistas.ufg.br/geoambiente } \\
\text { Jataí-GO | n 31 | Maio-Agos/2018 }\end{array}$ & $\begin{array}{c}\text { :GEO } \\
\text { U. AMBIENTE } \\
\text { G }\end{array}$ \\
\hline
\end{tabular}

conforme Pereira et al. (2012) na Plataforma Nordeste, na Formação Aquidauana, subunidade CPa, constituída por interestratificações de litótipos predominantemente arenosos, associados a siltitos, argilitos e folhelhos rítmicos (BRASIL, 1983). Sobre a gênese dessa cuesta existem duas hipóteses, uma baseada em fenômenos gerais de circundesnudação (AB'SABER, 1949) e outra baseada em soerguimento por efeitos isostáticos sem tectonismo (TEIXEIRA, 1932; GUERRA et al. 1989). Nesse contexto, Casseti (2005) prefere seguir na mesma linha de Teixeira (1932), indicando possível falhamento na base da escarpa.

Figura 1 - Localização da área de estudo em Caiapônia (GO)

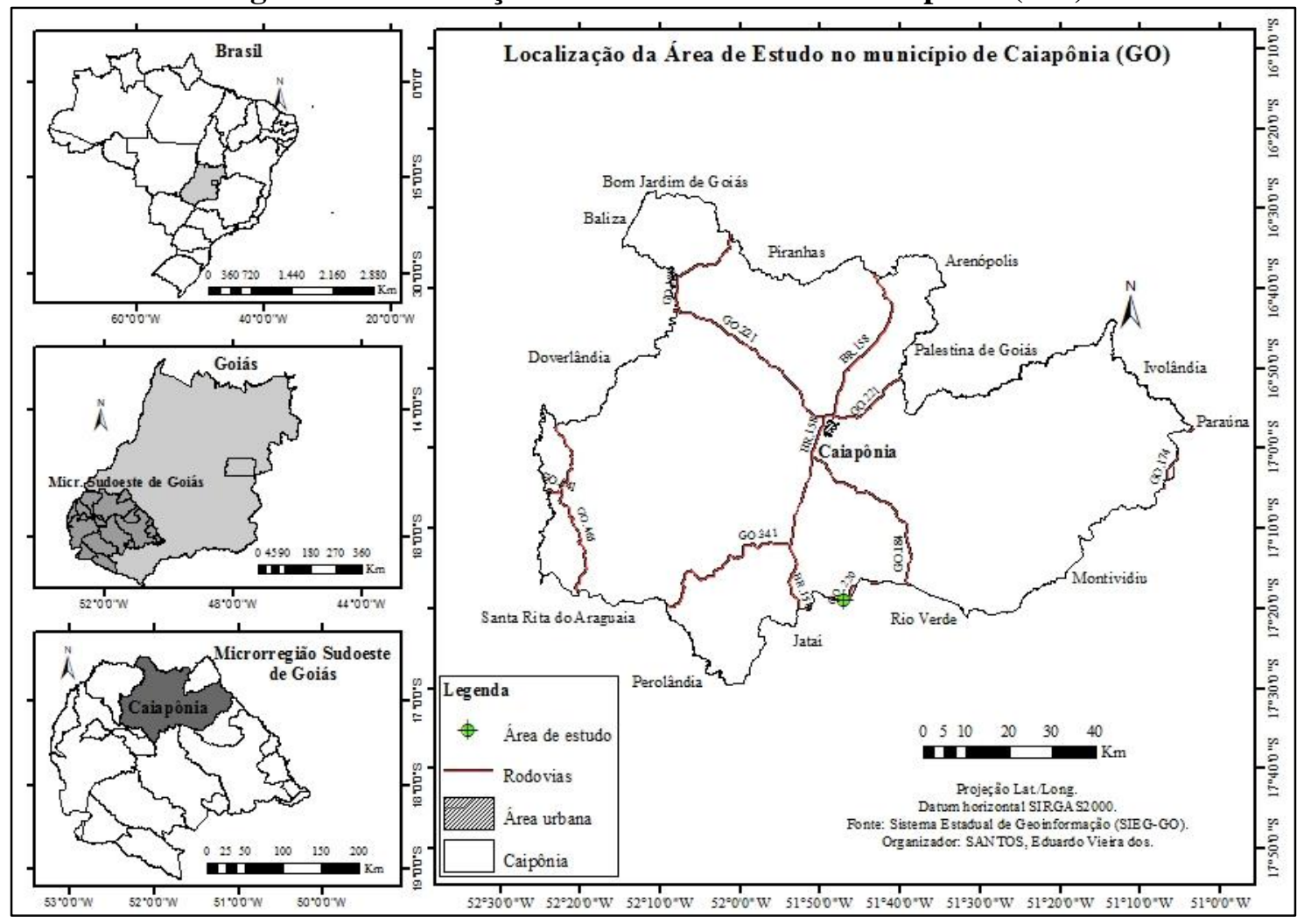

Fonte: Elaborado pelos autores a partir de bases de dados disponibilizadas pelo SIEG (2017).

Geomorfologicamente, a área em estudo está inserida no Planalto dos Guimarães (Alcantilados) (BRASIL, 1983), entre 930 e 855 m de altitude. Apresenta dissecação mediana e está inserida na unidade de Formas Tabulares, com relevos de topo aplainado, com diferentes ordens de grandeza e aprofundamento de drenagem, eventualmente separados por vales de fundo plano (BRASIL, 1983). Climaticamente a Microrregião Sudoeste de Goiás inclui-se quase inteiramente nas áreas tropicais de continentalidade pronunciada, dotadas de um longo período chuvoso durante o ano, opondo-se a outro, mais seco (AB'SABER; 


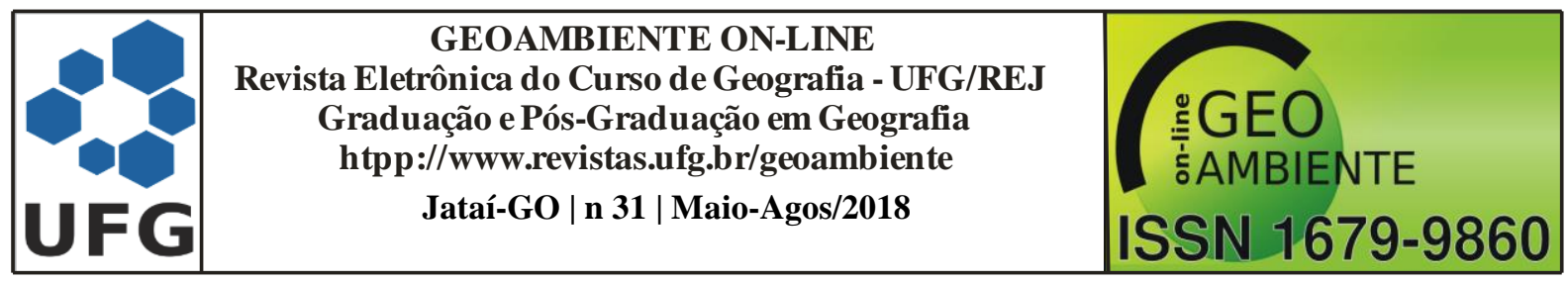

COSTA JR., 1951). Em um contexto regional, o solo predominante no local é o Latossolo Vermelho Distrófico de textura média, mas pode ocorrer também Neossolo Quartzarênico Distrófico (BRASIL, 1983). O entorno da Vereda foi ocupado por pastagens voltadas para pecuária, mas originalmente essa área era ocupada por Formações Típicas do Cerrado.

A Vereda em questão trata-se de uma nascente na bacia do rio do Rio Claro, que corre ortoclinalmente a cuesta do Caiapó até atingir sua frente escarpada e abre então uma percée cataclinal, passando a drenar seu reverso (BRASIL, 1983). De acordo com Casseti (2005) em determinados trechos, o Rio Claro, pode estar vinculado a provável linha de falha, o que teria permitido o deslocamento de blocos, originando escarpa de falha e preservando a disposição geral do mergulho das camadas (CASSETI, 2005).

\section{Coleta e análise de dados}

Foi feito o mapeamento do relevo, com a caracterização hipsométrica e de declividade. Nessa etapa, foi utilizada a imagem 17S525 da Shuttle Radar Topography Mission (SRTM) disponibilizadas pelo Instituto Nacional de Pesquisas Espaciais (INPE) no projeto Topodata, resolução espacial de $30 \times 30 \mathrm{~m}$. Para a confecção do material cartográfico utilizou-se o software Arc Gis, 10.1, licença do Laboratório de Geoinformação da UFG, Regional de Jataí (Environmental Systems Research Institute - ESRI). A partir da imagem SRTM foram geradas curvas de nível com equidistância de 15 m, com uso da ferramenta Contour. Posteriormente, com o uso da ferramenta Slope, foi gerada uma Carta de Declividade, reclassificada para as classes de declividade estipuladas pela EMBRAPA (1979), com o uso da ferramenta Reclassify.

As Veredas apresentam diferentes zonas morfopedológicas, as quais variam em função do relevo e consequente graus de umidade do solo (MELO, 2008; MELO, ESPINDOLA, 2006): 1. Zona de umidade sazonal (da borda da Vereda até a média vertente); 2. Zona úmida (a média-baixa vertente); 3. Zona encharcada (o fundo brejoso, encharcado). Todavia, devido à atividade antrópica, a zona de umidade sazonal já foi parcialmente ocupada, dificultando a delimitação exata dos limites entre as zonas. Dessa forma, para o levantamento da vegetação, optou-se por diferenciar apenas duas zonas amostrais: Zona encharcada e Zona úmida, denominadas respectivamente, como Zonas com buriti (CB) e sem buriti (SB). Ao passo que, para as coletas de solos, manteve-se as três zonas reconhecidas pelos autores supracitados. 


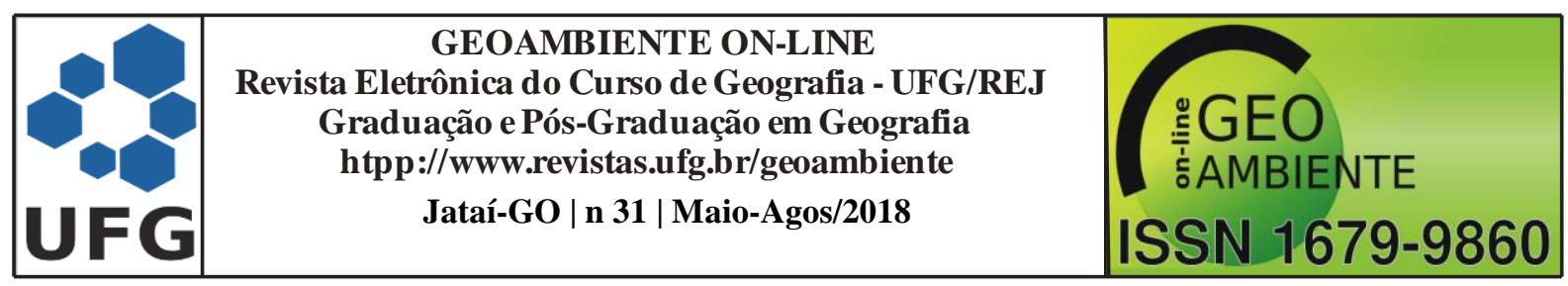

As atividades de campo foram realizadas em novembro de 2016, e para o levantamento florístico e fitossociológico da vegetação, foram demarcados 18 parcelas amostrais de $5 \times 10 \mathrm{~m}\left(50 \mathrm{~m}^{2}\right)$, totalizando 0,09 hectares, sendo 10 parcelas na zona $\mathrm{CB}$ e oito na zona SB. O levantamento florístico incluiu todas as espécies registradas dentro das parcelas, de hábito arbustivo-arbóreo com indivíduos acima de $1 \mathrm{~m}$, e as espécies foram identificadas no próprio campo. No levantamento fitossociológico adotou-se dois critérios de inclusão. O primeiro incluiu a contagem do número total de indivíduos lenhosos dentro das parcelas que tinham mais de $1 \mathrm{~m}$ de altura. O segundo critério amostrou todos os indivíduos arbóreos, com DAP (diâmetro à altura do peito a 1,30m do solo) $\geq 5 \mathrm{~cm}$. Portanto, o segundo critério envolveu apenas indivíduos arbóreos, em geral, adultos, ou seja, em estágio reprodutivo. Todos os indivíduos tiveram suas alturas estimadas visualmente. Para o primeiro critério fez-se análises apenas do registro de ocorrência e abundância de espécies por parcela. No segundo critério, as plantas tiveram o diâmetro medido e, portanto, além do registro de ocorrência e abundância, também calculou-se a área basal, e o valor de importância (VI) para cada espécie. Também foram calculados os índices de diversidade de Shannon (H') e a equabilidade de Pielou (J') (BROWER; ZAR, 1984). Os dados foram tabulados e analisados em planilhas eletrônicas Excel2010. Todas as análises foram feitas comparativamente entre CB e SB. Realizou-se um teste $t$ para comparar a densidade média de plantas nas parcelas com e sem buritis.

A coleta de solo foi efetuada com a retirada de uma amostra em cada uma das três zonas da Vereda, seguindo metodologia proposta por Santos et al. (2013a). Em cada ponto de coleta foram retiradas $0,5 \mathrm{~kg}$ de solo/sedimentos na camada superficial e subsuperficial, profundidades de $0-30 \mathrm{~cm}$ e $30-60 \mathrm{~cm}$, respectivamente, e registrada as coordenadas geográficas com o auxílio de receptor de Global Navigation Satellite System (GNSS). As amostras de solos e sedimentos foram colocadas em sacos plásticos, devidamente identificadas, e enviadas ao Laboratório de Solos da UFG, Regional de Jataí. Foram realizadas as seguintes análises físico-químicas: potencial hidrogeniônico $(\mathrm{pH})$, acidez do solo potencial $(\mathrm{H}+\mathrm{Al})$, Alumínio $(\mathrm{Al})$, Cálcio $(\mathrm{Ca})$, Magnésio $(\mathrm{Mg})$, Potássio $(\mathrm{K})$, Potássio disponível $\left(\mathrm{K} \mathrm{mg} / \mathrm{dm}^{3}\right)$, matéria orgânica $(\mathrm{MO})$; soma de bases $(\mathrm{SB})$, capacidade de troca catiônica (CTC), saturação por bases (V\%), areia, silte e argila.

\section{RESULTADOS E DISCUSSÃO}




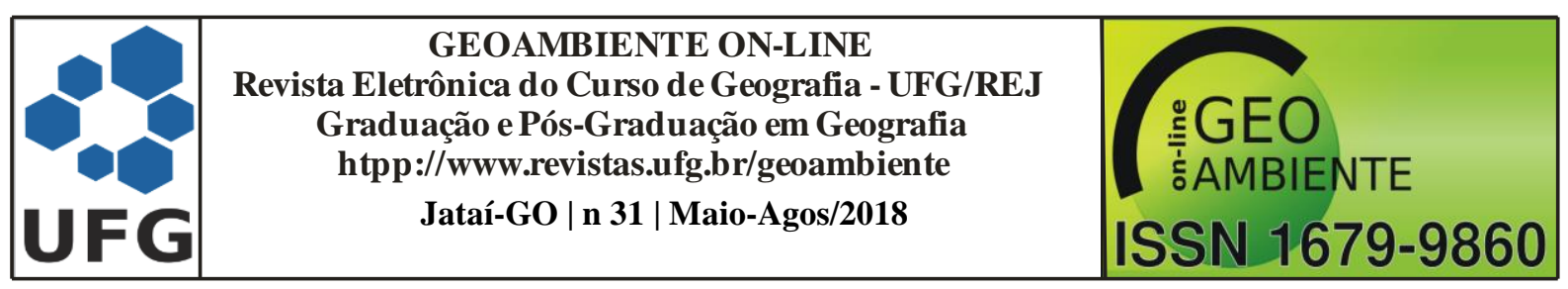

Aspectos geomorfológicos e edáficos

A Vereda estudada apresenta perfil topográfico com vertentes sub-retilíneas ou ligeiramente convexas, formando um vale aberto na sua porção superior. À medida que se afasta desta porção, o perfil topográfico tende a apresentar vale um pouco mais encaixado. A Vereda é cercada pela cuesta do Caiapó com declividades entre 45 e 75\%, e áreas menores com declividades superiores a 75\% (Figura 2). O limite sul e sudoeste da área adjacente da Vereda são marcados pelo sopé da escarpa com altas declividades, já as demais porções da área adjacente a Vereda são marcadas por pequenas elevações de topo plano a suaveondulado. O interior da Vereda está em áreas de declividade entre 3-8\% e 8-20\%, mais especificamente, áreas com declividade de 5\% e de 10\%. Dois estudos realizados em Veredas no município de Uberlândia-MG (LIMA, QUEIROZ NETO, 1996; GUIMARÃES, ARAÚJO, CORRÊS, 2002) registraram valores de declividade inferiores aos encontrados no presente estudo, respectivamente, $3 \%$, e $4,1 \%$ a $7,2 \%$.

Figura 2 - Declividade da área estudada em Caiapônia (GO) 

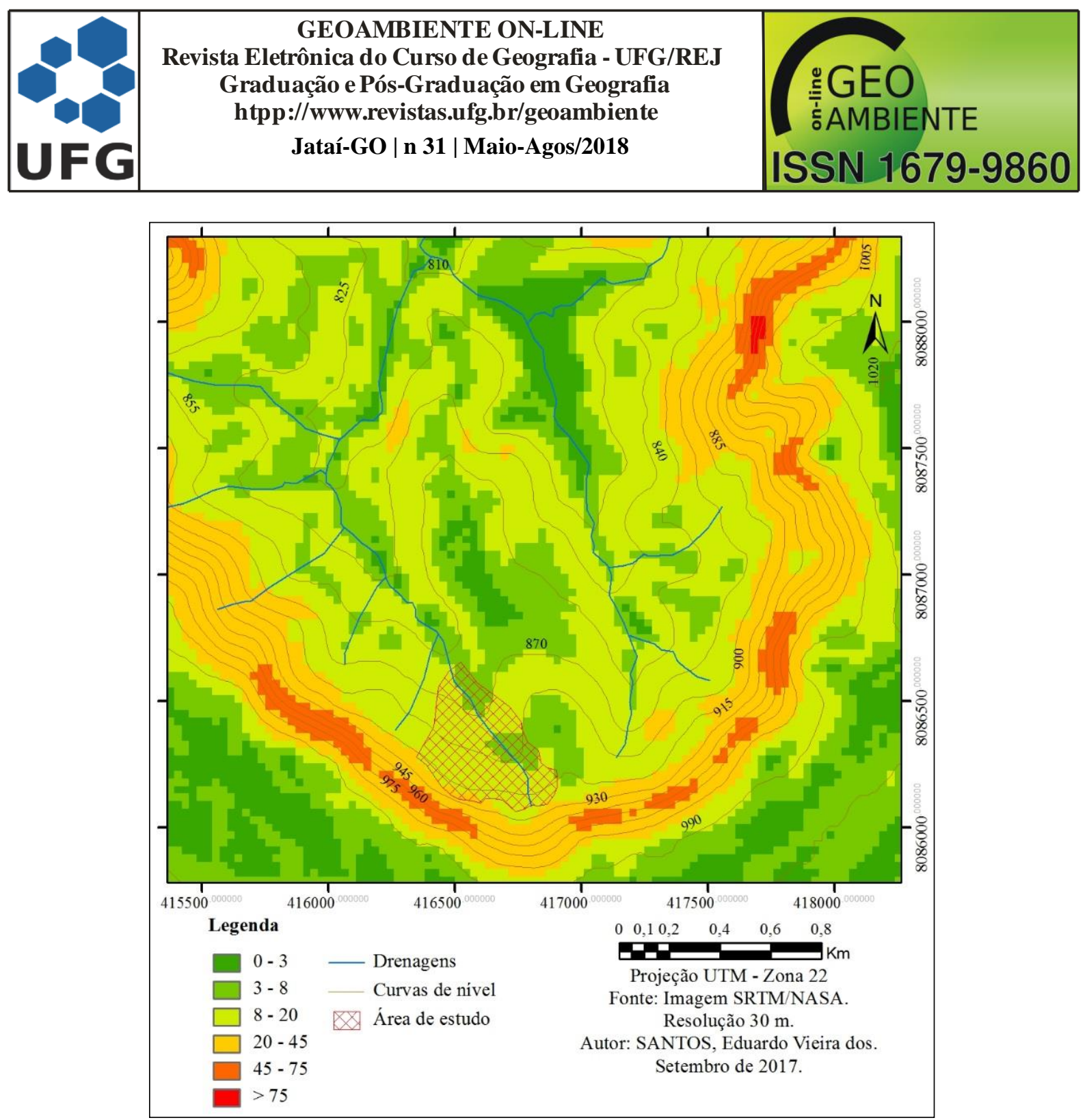

Fonte: INPE-Topodata - 2017.Organização: SANTOS, Eduardo Vieira dos - 2017.

Diante da caracterização geomorfológica da área e com base em Ferreira (2005/2006) a Vereda em análise pode ser enquadrada no subtipo Vereda de Sopé de Escarpa. Ao analisar a relação entre geomorfologia e composição florística em Veredas, Carvalho (1991) demonstra a existência de quatro estágios evolutivos que iniciam com superfície plana à suave ondulada e campo graminoso-herbáceo e filetes de buriti, até o estágio mais evoluído de vale encaixado, solo melhor drenado e aumento da vegetação arbórea juntamente com indivíduos adultos de buriti. Veredas em vales mais encaixados estariam em estágios evolutivos mais avançados, com espécies arbóreas ao longo da linha de drenagem e tendência a instalação de fisionomia florestal (CARVALHO, 1991). Nesse sentido, Veredas com declividades menores estariam em estágio inicial de evolução, mas como as declividades encontradas no presente estudo são ligeiramente mais elevadas, isto sugere que a Vereda em questão já não está nesse estágio inicial, tendo a um estágio intermediário de evolução. 


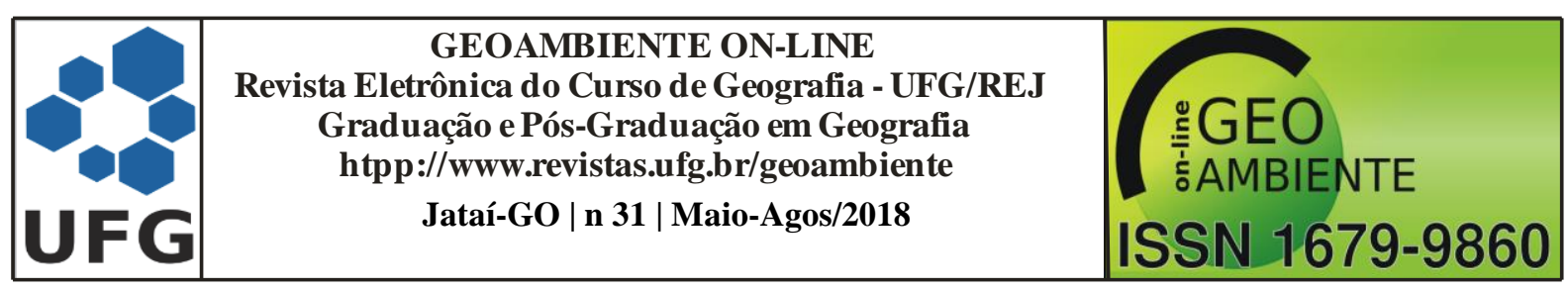

A análise química do solo (Tabela 1) mostrou acidez ativa $(\mathrm{pH})$ muito elevada para a zona encharcada e elevada para a zona úmida e a zona de umidade sazonal, segundo classificação de Alvarez et al. (1999). Solos ácidos são comumente encontrados nesses ambientes, conforme registrado em outros estudos (RAMOS, 2006; BISPO, 2010; PASSOS, 2015). A elevação do valor do pH das camadas superficiais para as camadas subsuperficiais, geralmente ocorre em consequência das condições redutoras, pela presença constante de água no perfil (BISPO, 2010). A elevada acidez também pode estar relacionada com o alto nível de impacto ambiental, situação demonstrada por Ávila et al. (2016), que encontrou pH mais ácido em áreas de Vereda não preservada, do que em áreas de Vereda preservada.

Tabela 1 - Resultados das análises físico-químicas de solo na Vereda em Caiapônia (GO), para Zona de umidade sazonal (ZUS), Zona úmida (ZU) e Zona encharcada (ZE)

\begin{tabular}{lcccccc}
\hline \multicolumn{1}{c}{ Propriedades edáficas } & ZUS 0-30 & ZUS 30-60 & ZU 0-30 & ZU 30-60 & ZE 30-30 & ZE 30-60 \\
\hline $\mathrm{pH}\left(\mathrm{H}_{2} \mathrm{O}\right)$ & 4,93 & 5,07 & 4,91 & 4,92 & 3,82 & 3,88 \\
$\mathrm{H}+\mathrm{Al}$ & 3,18 & 2,56 & 3,84 & 3,45 & 7,13 & 6,93 \\
$\mathrm{Al}$ & 0,8 & 0,8 & 1,28 & 1,16 & 4,42 & 4,53 \\
$\mathrm{Ca}$ & 0,15 & 0,05 & 0,16 & 0,41 & 0,08 & 0,12 \\
$\mathrm{Mg}$ & 0,07 & 0,02 & 0,03 & 0,07 & 0,02 & 0,01 \\
$\mathrm{Ca}+\mathrm{Mg}$ & 0,22 & 0,07 & 0,19 & 0,48 & 0,1 & 0,13 \\
$\mathrm{~K}$ & 0,072 & 0,06 & 0,048 & 0,048 & 0,116 & 0,104 \\
$\mathrm{~K}(\mathrm{~K} \mathrm{mg/dm})$ & 28,2 & 23,5 & 18,8 & 18,8 & 45,4 & 40,7 \\
$\mathrm{P}$ & 1,69 & 1,23 & 1,17 & 0,84 & 2,66 & 2,4 \\
$\mathrm{MO}$ & 12,56 & 10,54 & 11,87 & 14,07 & 19,8 & 16,48 \\
$\mathrm{SB}$ & 0,29 & 0,13 & 0,24 & 0,53 & 0,22 & 0,23 \\
$\mathrm{CTC}$ & 3,48 & 2,69 & 4,08 & 3,98 & 7,34 & 7,16 \\
$\mathrm{~V} \%$ & 8,4 & 4,84 & 5,83 & 13,28 & 2,95 & 3,27 \\
Areia (\%) & 79,79 & 79,34 & 67,64 & 66,75 & 52,07 & 51,47 \\
Silte (\%) & 8,95 & 9,97 & 13,46 & 12,66 & 26,45 & 26,13 \\
Argila (\%) & 11,26 & 10,69 & 18,9 & 20,59 & 21,48 & 22,4 \\
\hline
\end{tabular}

Fonte: Análise de solo - Laboratório UFG-RJ - 2016. Organização dos Autores (2017).

Os valores de pH e Al limitam a disponibilidade de nutrientes, que já é baixa, como pode-se visualizar nos cátions trocáveis, os níveis de $\mathrm{Ca}, \mathrm{Mg}$ são baixos e de $\mathrm{K}$ é muito baixo. Tais características podem ser fator de limitação para espécies mais exigentes quanto à fertilidade do solo. Reflexo da baixa disponibilidade de $\mathrm{Ca}, \mathrm{Mg}, \mathrm{K}$ é a soma de bases (SB) muito baixa para toda as zonas, conforme classificação de Alvarez et al. (1999). Ocorreu um pequeno aumento de $\mathrm{Ca}$ e $\mathrm{Mg}$ da camada superficial para a camada subsuperficial da zona 


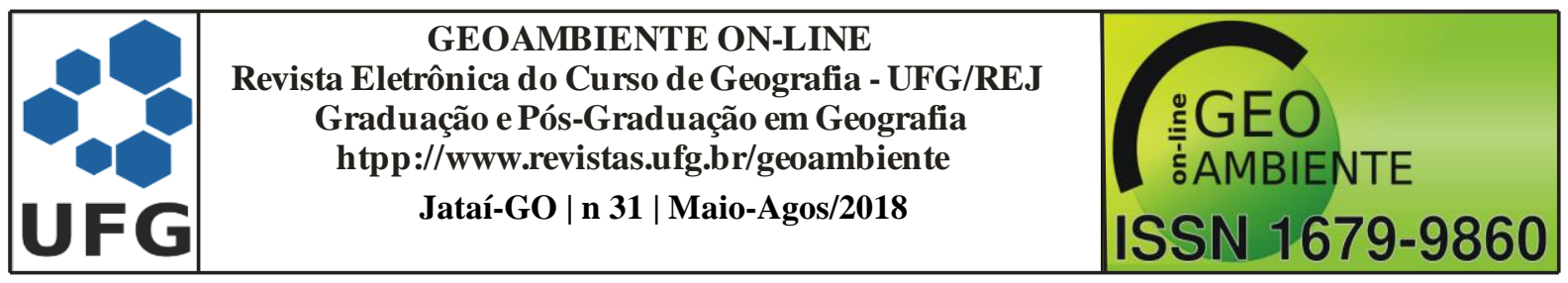

encharcada e da zona úmida, o mesmo não ocorreu na zona de umidade sazonal. Essa situação está relacionada com a taxa de difusão do oxigênio nas camadas do solo e a atividade dos microrganismos redutores de ferro, pois a saturação sazonal de água nas camadas subsuperficiais provoca um deslocamento do Ca e $\mathrm{Mg}$ dos sítios de troca, aumentando os seus teores em profundidade, principalmente, se a drenagem for impedida (BISPO, 2010).

Segundo classificação de Alvarez et al. (1999), a CTC é baixa para a zona úmida e de umidade sazonal, e média para a zona encharcada. Os maiores valores de CTC, na zona encharcada, relacionam-se com acúmulo da argila lixiviada das porções mais elevadas. $\mathrm{O}$ acúmulo de argila na zona encharcada possivelmente está associado ao lento transporte de material mais fino em suspensão das partes mais altas (RAMOS, 2006). Todas as amostras de solos apresentam baixa saturação por bases (V\% < 50\%), demonstrando o caráter distrófico desses solos (EMBRAPA, 2013). Esses resultados são indicativos da presença de sílica $\left(\mathrm{SiO}_{2}\right)$, a qual pode estar relacionada com a presença dos buritis.

Os teores de matéria orgânica apresentam um acréscimo da zona de umidade sazonal para a zona encharcada, situação similar à encontrada por Ramos (2006), e explicada como sendo em função da menor aeração. As condições de drenagem na zona encharcada proporcionam maior acúmulo de matéria orgânica, uma vez que a anaerobiose minimiza drasticamente a ação dos microrganismos decompositores, predominantemente aeróbicos (BREEMEN; BUURMAN, 2002).

A análise física do solo mostrou maior percentual de areia e menores para silte e argila no sentido da zona de umidade sazonal em direção à zona encharcada. Resultados semelhantes também foram encontrados em outros estudos (RAMOS, 2000; 2006; ARAÚJO et al., 2002; OLIVEIRA, 2005; MELO, 2008; BISPO, 2015), sugerindo que as Veredas diferem quanto a textura do solo em suas diversas zonas. Segundo Ramos (2000) a variação textural dos solos em Veredas está relacionada, em parte, à contribuição de sedimentos transportados do topo da paisagem para o sopé.

Com base na análise física do solo e nas classes texturais do solo (EMBRAPA, 1979), nota-se que o solo da zona de umidade sazonal apresenta textura franco-arenosa; da zona úmida, textura franco-arenosa na camada superficial e franco-argilo arenosa na camada subsuperficial. Já o solo da na zona encharcada apresenta textura franco-argilo arenosa. Na camada superficial a oscilação do lençol freático é mais intensa que nas camadas subsuperficiais que permanecem saturadas com água, provocando ciclos de redução e 


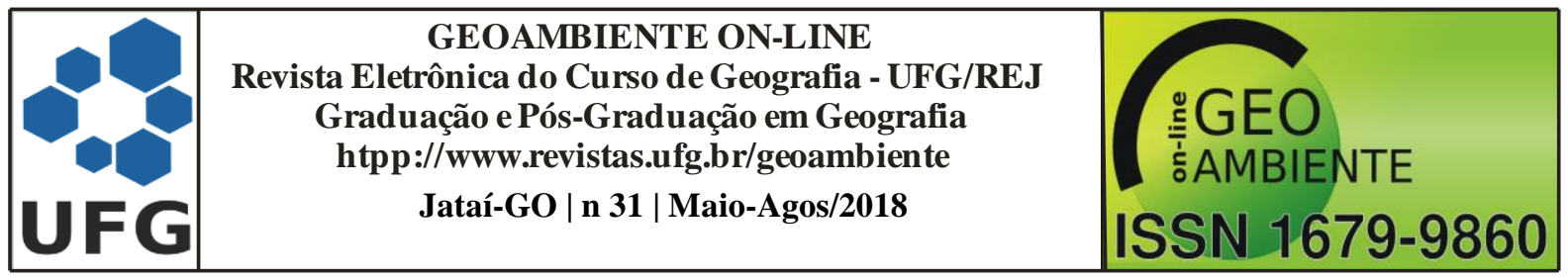

oxidação do ferro, assim, a destruição dos argilominerais é mais frequente nos horizontes superficiais (BISPO, 2015), o que contribui para a diferenciação textural entre a camada superficial e subsuperficial.

Todavia, nesse contexto, Oliveira (2005) afirma que embora a textura do solo possa influênciar na retenção de água pelo solo, no seu estudo, a variação na riqueza de espécies entre Veredas com solos arenosos e Veredas com solos argilosos, não foi influênciada diretamente pela textura dos solos, mas, possivelmente, por alterações antrópicas. Embora, devido ao reduzido número de estudos sobre o tema, tais considerações não possam ser generalizadas para todas as Veredas. Para Ramos et al. (2006) e Resende (2010) a topografia do terreno pode ser mais determinante no estabelecimento das zonas de umidade e na ocorrência e distribuição florística das Veredas, do que a textura do solo. Entretanto, não se pode desconsiderar que a variação no substrato, especialmente na umidade do solo, fertilidade e topografia, influencia a distribuição de espécies arbóreas (PINTO; OLIVEIRA-FILHO; HAY, 2005). Nesse sentido, verifica-se a necessidade de mais estudos que correlacionem características do solo e características do relevo com o tipo de vegetação presente em área de Vereda.

\section{Aspectos florísticos e fitossociológicos}

$\mathrm{Na}$ Vereda em estudo foi registrado um total de 559 indivíduos, pertencentes a 31 espécies, 22 famílias (Tabela 3). Melastomataceae foi a família mais rica, com seis espécies, tendo sido também elencada por Guimarães et al. (2002), como integrantes das principais famílias registradas em estudos relacionados à vegetação campestre. Melastomataceae também é família comum de várias outras fitofisionomias de Cerrado e de áreas florestais de forma geral, além de estar entre os maiores grupos de espécies encontradas no Brasil (SOUZA; LORENZI, 2005). Outras 17 famílias botânicas apresentaram apenas uma espécie cada. De acordo com Araújo (2002) um grande número de famílias com uma única espécie pode ser devido à sua sensibilidade potencialmente maior à perturbação antropogênica (ARAÚJO et al., 2002). Entretando o reduzido número de espécies por família também pode estar relacionado aos altos teores de umidade do solo que contribuem para a restrição à ocorrência de espécies menos adaptadas a esta característica.

Registramos nesse estudo, maior riqueza florística nas parcelas com buriti (CB), nas quais foram registrados 398 indivíduos e 28 espécies, sendo que mais de $70 \%$ ocorreram 


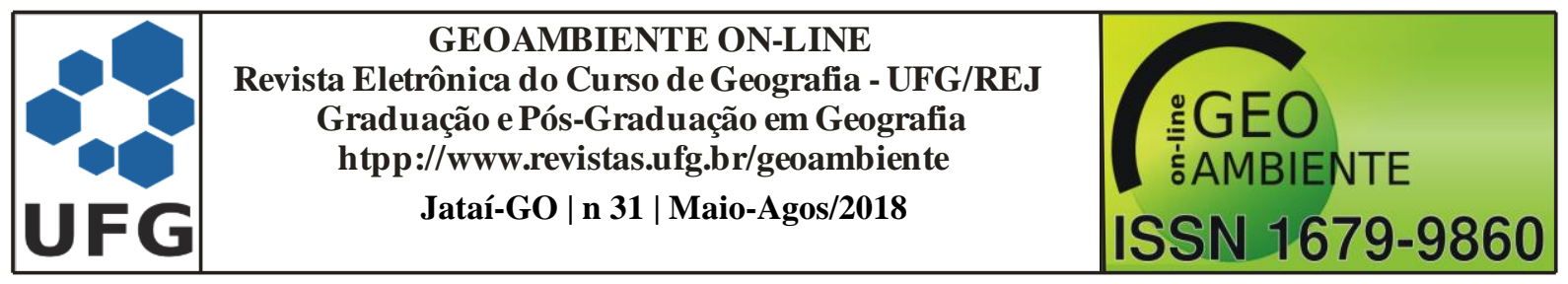

exclusivamente nessa zona. Em SB foram registrados 161 indivíduos de 11 espécies, sendo que apenas $27,3 \%$ ocorreram exclusivamente nessa zona. Do total de espécies registradas, oito são comuns aos ambientes CB e SB. A riqueza vegetal registrada na área de pesquisa foi menor do que aquela registrada em Uberlândia - MG (ARAÚJO et al., 2002; GUIMARÃES, ARAÚJO, CORRÊA, 2002). Entretanto, esses autores também registraram espécies do estrato herbáceo, mostrando que a representatividade florística de ervas em áreas de Veredas é substancial, englobando mais de 52\% das espécies nesse estrato (ARAÚJO et al.; 2002). A baixa riqueza de espécies registradas nesta pesquisa, também pode estar relacionada com a intensidade da ação antrópica no local, tendo em vista que a riqueza aumenta em pastejo moderado e declina em pastejo intenso (MILCHUNAS; SALA; LAUENROTH, 1988), e a Vereda em estudo já sofreu diversos impactos como a ocupação parcial de sua Zona de Umidade Sazonal, por pastagem, e também, observou-se o constante pisoteio por gado em seu interior, demonstrando uma ocupação intensa.

As espécies com maior número de indivíduos foram Miconia chamissois (185 indivíduos), Mauritia flexuosa (68), Tapirira guianensis (64), Piper sp. (56), Cecropia pachystachya (42), Piper aduncum (38), Miconia sp.1 (32) e Lauraceae sp. (12), as demais espécies tiveram número de indivíduos inferior a dez. O número médio de indivíduos foi significativamente maior em $\mathrm{CB}$ do que em SB $(\mathrm{t}=3,595 ; P=0,0013 ; \mathrm{gl}=15)$.

Em SB, Miconia chamissois englobou quase $60 \%$ dos indivíduos. De um modo geral, a Vereda estudada apresenta sinais de impactos por atividades antrópicas e tais impactos podem influenciar a composição florística. A grande ocorrência de $M$. chamissois se deve ao fato desta ser uma espécie típica de solos mais encharcados (OLIVEIRA, 2005), além do gênero Miconia pertencer à família que é importante em ambientes mal preservados (GUIMARÃES, ARAÚJO, CORRÊA, 2002; ÁVILA et al., 2016).

Tabela 3 - Famílias e espécies registradas no levantamento florístico em áreas com $(\mathrm{CB})$ e sem (SB) buritis, e respectivas abundâncias, no Sudoeste Goiano - 2017

\begin{tabular}{lccc}
\hline Famílias / Espécies & \multicolumn{3}{c}{ N. indivíduos } \\
\hline Anacardiaceae /Tapirira guianensis Aubl. & CB & SB & Total \\
Annonaceae /Xylopia aromatica (Lam.) Mart. & 63 & 1 & 64 \\
Annonaceae /Xylopia emarginata Mart. & & 1 & 1 \\
Aquifoliaceae /Ilex affinis Gardner & 1 & 1 \\
\end{tabular}




\begin{tabular}{|c|c|c|}
\hline & $\begin{array}{c}\text { GEOAMBIENTE ON-LINE } \\
\text { Revista Eletrônica do Curso de Geografia - UFG/REJ } \\
\text { Graduação e Pós-Graduação em Geografia } \\
\text { htpp://www.revistas.ufg.br/geoambiente } \\
\text { Jataí-Go | n 31 | Maio-Agos/2018 }\end{array}$ & $\begin{array}{c}\text { GEO } \\
\text { G G }\end{array}$ \\
\hline \multirow{2}{*}{ GMBIENTE } & $1679-9860$ \\
\hline
\end{tabular}

Arecaceae /Mauritia flexuosa L.f.

$68-68$

Asteraceae / Asteraceae sp

$\begin{array}{ll}7 & 7\end{array}$

Burseraceae /Protium heptaphyllum (Aubl.) Marchand

Calophyllaceae /Calophyllum brasiliense Cambess.

Cyatheaceae /Cyatheadelgadii Sternb.

Euphorbiaceae /Alchornea triplinervia (Spreng.) Müll. Arg.

Euphorbiaceae / Maprounea guianensis Aubl.

Indeterminada / Indeterminada 1

Lauraceae /Ocotea sp

Melastomataceae /Miconia albicans (Sw.) Triana

$1 \quad 1$

Melastomataceae / Miconia chamissois Naudin

Melastomataceae / Miconia sp

Melastomataceae / Pleroma stenocarpum (Schrank et Mart. ex DC.) Triana

$1 \quad 1$

$4 \quad 1 \quad 5$

$1 \quad 1$

Melastomataceae / Tococa guianensis

Melastomataceae / Trembleya parviflora (D. Don) Cogn.

Moraceae /Ficus sp

Myristicaceae /Virola sebifera Aubl.

Myrsinaceae /Myrsine guianensis (Aubl.) Kuntze

Phyllanthaceae /Hyeronima alchorneoides Allemão

Piperaceae /Piper aduncum L.

Piperaceae /Pipercf.fuligineum Kunth

Proteaceae /Euplassa incana (Klotzsch) I. M. Johnst.

Rubiaceae /Alibertia edulis (Rich.) A.Rich.

$\begin{array}{lll} & 1 & 1 \\ 1 & & \\ & & \end{array}$

Rubiaceae /Psychotria sp

$\begin{array}{lll}12 & & 12 \\ & 2 & 2\end{array}$

Siparunaceae /Siparuna guianensis Aubl.

$90 \quad 95 \quad 185$

Styracaceae /Styrax leprosus Hook. \& Arn.

$\begin{array}{lll}5 & 1 & 6\end{array}$

$1 \quad 1$

Urticaceae /Cecropia pachystachya Trécul

Total

Fonte: Levantamento em campo - 2016. Organização dos Autores (2017).

Espécies como Cecropia pachystachya e Piper aduncum, também abuntantes na área do presente estudo, foram relacionadas por Resende (2010) como espécies com boa representatividade em Veredas cercadas por pastagem e lavoura. Embora seja notória uma variação geomorfológica e fitofisionômica das Veredas presentes no Cerrado, que pode estar 


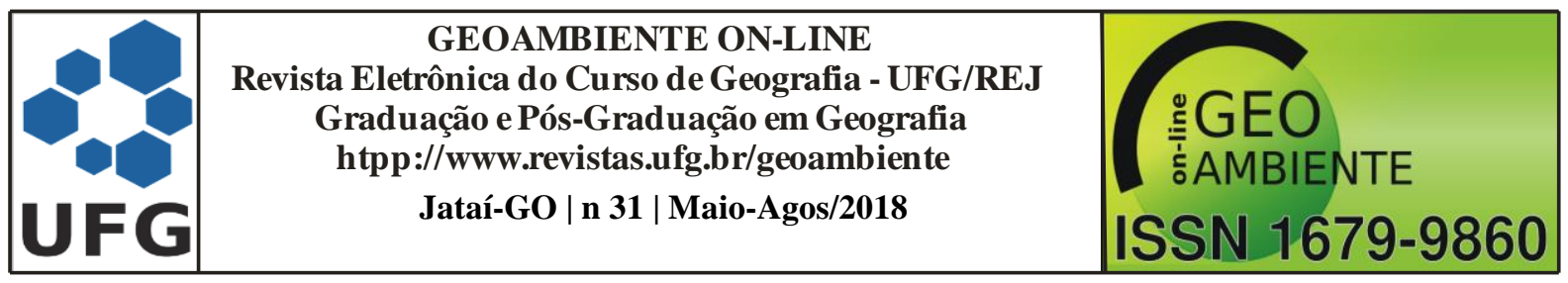

relacionada ao estágio evolutivo, ainda é possível encontrar similaridades florísticas. Em Veredas do município de Uberlândia (MG), Araújo et al. (2002) afirmam que Tapirira guianensis, Cecropia pachystachya, Miconia chamissois, Miconia theaezans e Ilex affinis foram encontradas formando moitas sob indivíduos adultos de Mauritia flexuosa. No nosso estudo, situação semelhante foi registrada, em que a vegetação da zona encharcada (CB) também apresenta espécies como Tapirira guianensis, Cecropia pachystachya, Miconia chamissois e Ilex affinis aglomeradas sob buritis. Tapirira guianensis e Cecropia pachystachya, presentes na zona encharcada, foram encontradas por Resende (2010) na zona úmida e do fundo nas três Veredas estudadas no município de Bela Vista de Goiás (GO), demonstrando que são espécies de ampla ocorrência em veredas. Estas mesmas espécies foram também encontradas em florestas de galeria no Distrito Federal por Pereira et al. (1985) e Mendonça et al. (1998). A presença de espécies de florestas de galeria em áreas de Veredas pode sugerir mudança em seu estágio sucessional devido ao constante assoreamento e modificações na rede de drenagem (CARVALHO, 1991), situação similar a encontrada no presente estudo, com a verificação da presença de sedimentos na zona encharcada da Vereda, região aqui denominada de zona com buritis.

Diante da análise de outros estudos efetuados em Vereda (ARAÚJO et al., 2002; GUIMARÃES, ARAÚJO, CORRÊA, 2002; RESENDE, 2010), era esperado que a zona úmida estivesse sendo ocupada por espécies de outras formações do Cerrado. Todavia, essa ocupação não foi registrada, provavelmente porque o Cerrado adjacente foi desmatado, e ainda porque a zona úmida apresenta alta umidade, impedindo o estabelecimento de espécies menos adaptadas.

O levantamento fitossociológico realizado para árvores adultas amostrou 51 indivíduos, distribuídos em oito espécies e oito famílias (Tabela 4). As famílias com maior número de indivíduos foram Anacardiaceae (19 indivíduos), Arecaceae (15) e Urticaceae (11).

Nas parcelas SB houve baixa densidade de indivíduos e exclusividade de Cecropia pachystachya (5 indivíduos). Essa diferença na densidade entre parcelas CB e SB provavelmente se deve ao fato da vereda em estudo apresentar nas zonas úmidas e de umidade sazonal, vegetação de hábito herbáceo-arbustivo, indicando ambiente de vereda em estágio mais jovem de evolução. Esta exclusividade da ocorrência de embaúba em SB, demonstra o predomínio de vegetação herbácea-arbustiva na zona úmida. 


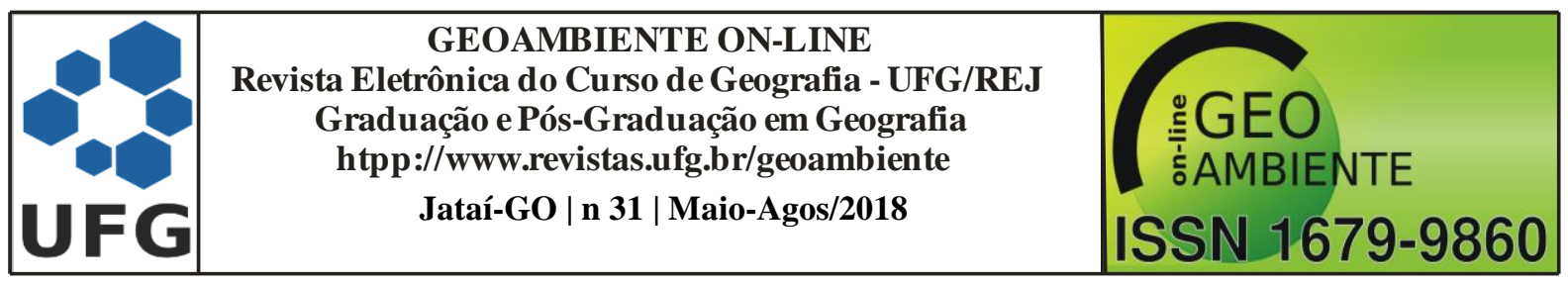

Tabela 4. Parâmetros fitossociológicos das espécies registradas nas zonas com buriti (CB) e (SB), ordenadas por ordem de valor de importância (VI), em uma Vereda no Sudoeste Goiano. - 2017

\begin{tabular}{lcccccccc}
\hline Espécies & Zona & NI & AB & P & DR & DoR & FR & VI \\
\hline Mauritia flexuosa & CB & 15 & 1,297 & 9 & 32,6 & 84,4 & 37,50 & 154,49 \\
Tapirira guianensis & CB & 19 & 0,129 & 5 & 41,3 & 8,4 & 20,83 & 70,55 \\
Cecropia pachystachya & CB & 6 & 0,059 & 4 & 13,0 & 3,8 & 16,67 & 33,55 \\
Styrax leprosus & $\mathrm{CB}$ & 2 & 0,013 & 2 & 4,3 & 0,8 & 8,33 & 13,50 \\
Indeterminada 1 & $\mathrm{CB}$ & 1 & 0,023 & 1 & 2,2 & 1,5 & 4,17 & 7,85 \\
Piper cf lhotzkyanum & $\mathrm{CB}$ & 1 & 0,009 & 1 & 2,2 & 0,6 & 4,17 & 6,94 \\
Hyeronima alchorneoides & $\mathrm{CB}$ & 1 & 0,005 & 1 & 2,2 & 0,3 & 4,17 & 6,66 \\
Alibertia edulis & $\mathrm{CB}$ & 1 & 0,002 & 1 & 2,2 & 0,1 & 4,17 & 6,47 \\
Cecropia pachystachya & $\mathrm{SB}$ & 5 & 0,020 & 4 & 100 & 100 & 100 & 300
\end{tabular}

NI: número de indivíduos, AB: área basal, P: parcelas, DR: densidade relativa, DoR: dominância relativa, FR: frequência relativa.

Fonte: Levantamento em campo - 2016. Organização dos Autores (2017).

Na zona CB, a espécie com maior VI foi Mauritia flexuosa, com aproximadamente $50 \%$ da importância total, seguido de Tapirira guianensis e Cecropia pachystachya. Buritis são considerados plantas predominantes e características de Veredas (FERREIRA, 2009; SANTOS et al., 2013b; ÁVILA et al., 2016). Tapirira guianensis apresentou maior número de indivíduos do que Mauritia flexuosa. Mesmo assim, sugerimos que a vereda em análise se encontra no estágio dois de evolução, descrito por Carvalho (1991), já que nos últimos estágios seria esperado maior presença de espécies arbóreas junto ao buriti e também nas zonas do meio e da borda.

O índice de diversidade registrado nesse estudo $\left(\mathrm{H}^{\prime}=1,50\right)$ é baixo quando comparado à Vereda no município de Bela Vista de Goiás-GO (RESENDE, 2010), cujos índices variaram de 2,80 a 3,4, entre Veredas alteradas e bem conservadas. Já Ávila et al. (2016) em estudo em Vereda na porção norte de Minas Gerais, registrou diversidade 2,64, ao passo que em estudo no Distrito Federal, Silva et al. (2016) registraram diversidade de 2,29. Resende (2010) e Ávila et al. (2016) avaliaram não só o estrato arbustivo-arbóreo, mas também o estrato herbáceo, e Silva et al. (2016) amostrou áreas com outras fitofisionomias de Cerrado adjacentes à Vereda, o que pode explicar o baixo índice de diversidade encontrado aqui. 


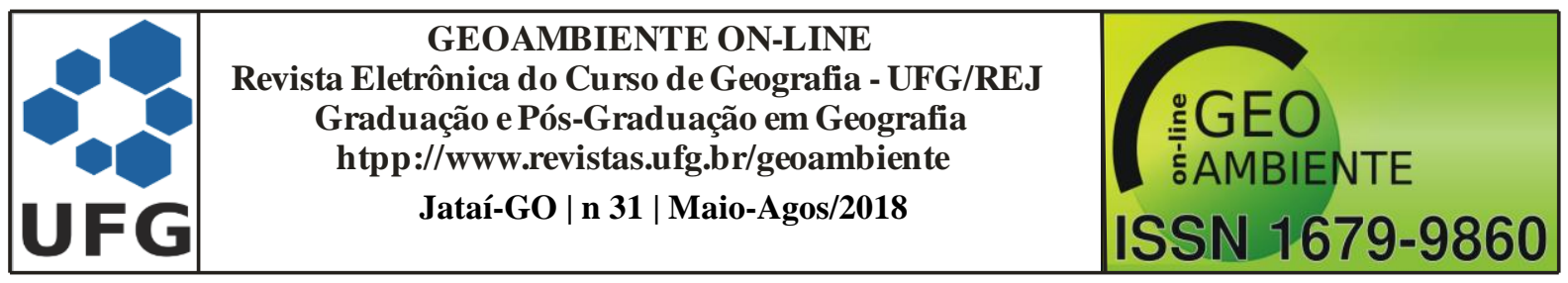

A Vereda em estudo apresenta sinais de ações antrópicas intensas, visto que parte de sua zona de umidade sazonal foi desmatada e ocupada por pastagem. Como não existe nenhum tipo de barreira impedindo o fluxo de gado no local, é notório o pisoteio em toda a extensão da Vereda, bem como a presença de espécies invasoras como braquiária. O plantio de pastagem exótica foi realizado, invadindo o ambiente de Vereda e a zona de umidade sazonal foi parcialmente ocupada. A atividade pecuária cerca toda extensão da Vereda.

\section{CONCLUSÕES}

Verifica-se que após o desenvolvimento da cuesta do Caiapó, por soerguimento acompanhado de falhamento na base da escarpa, processos erosivos iniciaram o entalhamento de pequenos vales, que ao interceptarem camadas geológicas de diferentes permeabilidades expuseram aquíferos, criando condições para o aparecimento da Vereda. Verificou-se altos teores de areia no solo, que está relacionado ao material de origem formado por litótipos predominantemente arenosos da Formação Aquidauana. Consequentemente, a ocorrência de buritis é condicionada pela sílica, evidenciada por um solo local bem lixiviado, distrófico e arenoso.

Os índices de declividade associados aos resultados do levantamento da vegetação, em que foram registradas a frequente presença de espécies arbóreas na zona encharcada, demonstra que a Vereda se enquadra no estágio dois de evolução, conforme classificação de Carvalho (1991). Contribui para uma evolução mais acelerada do ambiente de Vereda o aporte de sedimentos provenientes do entorno mal preservado.

A predominância da família Melastomataceae e do gênero Miconia no levantamento, reforçam a sua ocorrência em áreas úmidas no Planalto Central brasileiro, alem do que o gênero Miconia é comum em ambientes mal preservados. Tapirira guianensis e Cecropia pachystachya na zona encharcada, foram as principais espécies arbóreas co-ocorrendo com os buritis, e responsáveis pelo adensamento da Vereda, indicando esse avançado estágio sucessional da mesma. Houve grande distinção florística e estrutural ao longo da Vereda, o que indicou a ocorrência de duas zonas com características morfopedológicas distintas. Mauritia flexuosa foi a espécie mais importante registrada no estudo, caracterizando bem o ambiente da Vereda estudada.

A ação antrópica registrada no estudo, sugere influencia no processo sucessional da Vereda, inclusive com mudanças na diversidade de espécies,. Diante desses resultados 


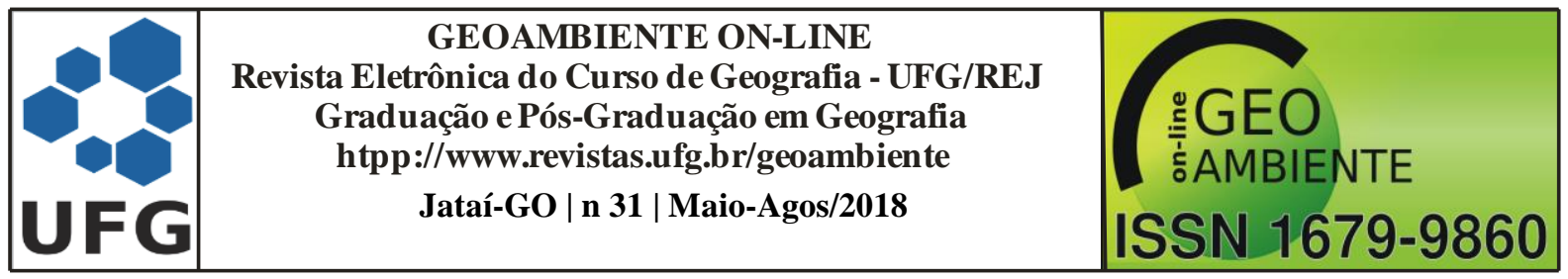

reforça-se a importância da realização de estudos que integrem informações do relevo, do solo e da vegetação para o melhor conhecimento do processo evolutivo dos ambientes de Vereda para a distinção de suas diferentes zonas.

\section{AGRADECIMENTOS}

Ao CNPq e à FAPEG, no âmbito do Projeto PELD Jataí - Pesquisas Ecológicas de Longa Duração (Processo No 2012/10267001108);ao CNPq pela bolsa Produtividade em Pesquisa (PQ2) ao FAG Guilherme. Aos professores Romário Rosa de Sousa da Universidade Federal de Mato Grosso, e Mírian Maria de Paula, da Universidade Estadual de Goiás, pelo auxílio prestado em campo e correções no presente texto.

\section{REFERÊNCIAS}

AB'SÁBER, A. N.; COSTA JR., M. Contribuição ao estudo do Sudoeste Goiano. Boletim de Geografia, Rio de Janeiro, v. 9, n. 98, p. 123-138, maio 1951.

AB'SÁBER, A. N. Regiões de circundesnudação pós-Cretáceas no Planalto brasileiro. Boletim Paulista de Geografia, São Paulo, v. 1, p. 3-21, mar. 1949.

AGUIAR, L. M. S.; CAMARGO, A. J. A. Cerrado: ecologia e caracterização. Planaltina: Embrapa Informação Tecnológica, 2004. 249 p.

ALVAREZ, V. H. et al. Recomendações para o uso de corretivos e fertilizantes em Minas Gerais. 5. Aproximação. Viçosa, MG: Comissão de Fertilidade do Solo do Estado de Minas Gerais, 1999.

ARAÚJO, G. M. et al. Composição florística de Veredas no município de Uberlândia, MG. Revista Brasileira de Botânica, São Paulo, v. 25, n.4, p. 475-493, dec. 2002. Disponível em: <http://dx.doi.org/10.1590/S0100-84042002012000012>. Acesso em: 22 nov. 2016.

ÁVILA, M. A. et al. Structure of natural regeneration in relation to soil properties and disturbance in two swamp forests. Cerne, Lavras, v. 22, n. 1, p. 1- 10, jan./mar. 2016. Disponível em: <http://dx.doi.org/10.1590/010477602016220120>. Acesso em: 20 fev. 2017. BAHIA, T. de O. et al. Florística e fitossociologia de Veredas em diferentes estágios de conservação na APA do Rio Pandeiros, norte de Minas Gerais. MG. BIOTA, Belo Horizonte, v. 2, n. 3, p. 14-21, ago./set. 2009. Disponível em: <http://www.ief.mg.gov.br/ images/stories/mg_biota/2014/mg.biota\%20v.2\%20n.3.pdf.>. . Acesso em: 20 fev. 2016. 


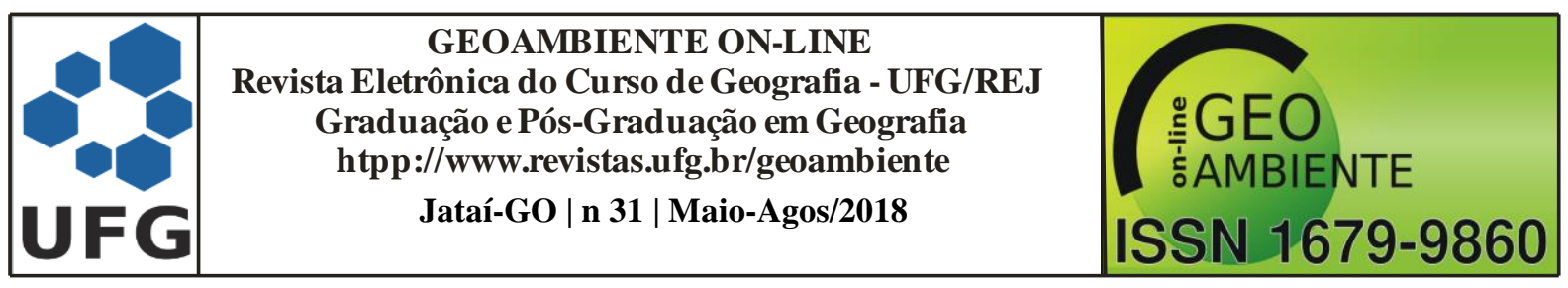

BISPO, F. H. A. Gênese e classificação de solos em topossequência de Veredas das chapadas do Alto Vale do Jequitinhonha - MG. (Mestrado em Ciências Agrárias) - Universidade Federal dos Vales do Jequitinhonha e Mucuri, Diamantina: UFVJM, 2010.

BOAVENTURA, R. S. Contribuição aos estudos sobre a evolução das Veredas. In: ENCONTRO NACIONAL DE GEÓGRAFOS, 3, 1978, Fortaleza. Comunicações... Fortaleza: [s. n.], 1978. p. 13-17.

Preservação das Veredas: síntese. In: ENCONTRO LATINO AMERICANO RELAÇÃO SER HUMANO-AMBIENTE, 2, 1988, Belo Horizonte. Anais... Belo Horizonte: FUMEC, 1988. p. 109-118.

BRASIL. Departamento Nacional de Produção Mineral. Projeto RADAMBRASIL: Folha SE.22 Goiânia. Rio de Janeiro: DNPM, 1983. (Levantamento de Recursos Naturais; 31).

BREEMEN, N. V.; BUURMAN, P. Soil Formation. 2. ed. Dordrecht: K. A., 2002.

BROWER, J. F.; ZAR, J. H. Field \& laboratory methods for general ecology. Dubuque, Iowa: WM. C. Brown Company Publishers, 1984.

CARVAlHO, P. G. S. As Veredas e sua importância no Domínio dos Cerrados. Informe Agropecuário, Belo Horizonte, v. 15, n. 168, p. 47-54, 1991.

CASSETI, V. Geomorfologia. [S. 1.], 2005. Disponível em: <http://www.funape.org.br/geomorfologia/>. Acesso em: 14 mar. 2017

CASTRO, J. P. C. As Veredas e sua proteção jurídica. Análise e Conjuntura, Belo Horizonte, v. 10, n. 5-6, p. 321-333, mai./jun. 1980.

DE-CAMPOS, A. B. et al. Spatial distribution of tropical wetlands in Central Brazil as influenced by geological and geomorphological settings. Journal of South American Earth Sciences, [S. 1.], v. 46, p.161-169, out. 2013. Disponível em: <http://www.sciencedirect.com/science/article/pii/S089598111100160X>. Acesso em: 28 set. 2017. EITEN, G. The Cerrado vegetation of Brazil. The Botanical Review, New York, v. 38, n. 2, p. 201-341, abr. 1972. Disponível em: <https://link.springer.com/article/10.1007\%2FBF02859158?LI=>. Acesso em: 05 nov. 2016. EMPRESA BRASILEIRA DE PESQUISA AGROPECUÁRIA. Serviço Nacional de Levantamento e Conservação de Solos. Súmula da $10^{\mathrm{a}}$ Reunião Técnica de Levantamento de Solos. Rio de Janeiro: EMBRAPA/SNLCS,1979. (Embrapa-SNLCS. Micelânea, 1). Sistema Brasileiro de Classificação de Solos. 3. ed. ver. Brasília: EMBRAPA, 2013. 


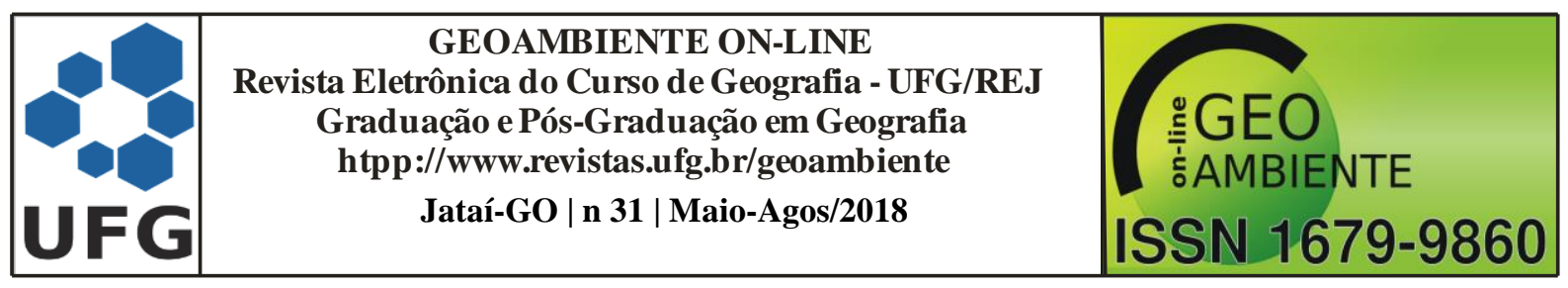

FAGUNDES, N. C. A.; FERREIRA, E. J. Veredas (Mauritia Flexuosa palm swamps) in the southeast Brazilian savanna: Floristic and structural peculiarities and conservation status. Neotropical Biology and Conservation, São Leopoldo, v. 11, n. 3, p. 178-183, set./dez. 2016. Disponível em: <http://revistas.unisinos.br/index.php/neotropical/article/view/nbc.2016.113.07>. Acesso em: 27 set. 2017.

FERREIRA, I. M. Aspectos paisagísticos do Cerrado: degradação das paisagens de Vereda. In: Encuentro de Geógrafos de América Latiana, 2009, 12, Montivideo. Anais do XII Encuentro de Geógrafos de América Latiana: Caminando em uma América Latina en transformación. Montivideo: Site do evento, 2009. v. Único. p. 1-15.

Modelos geomorfológicos das Veredas no ambiente de Cerrado. Espaço em Revista, Catalão, v. 7/8, n. 1, p. 7-16, jan/dez. 2005/2006.

O afogar das Veredas: uma análise comparativa espacial e temporal das Veredas do Chapadão de Catalão (GO). 2003. 242 f. Tese (Doutorado em Geografia) - Instituto de Geociências e Ciências Exatas, Universidade Estadual Paulista, Rio Claro, 2003.

Paisagens do Cerrado: um estudo do subsistema de Veredas. In: GOMES, H. (Coord.). Universo do Cerrado. Goiânia: UCG, 2008. v. 1.

FONSECA, V. S.; SILVA, I. M. Etnobotânica: base para conservação/I Workshop Brasileiro de Etnobotânica e Botânica Econômica. Nova Friburgo: EDUR, 1998. 131 p.

GOIÁS (Estado). Sistema Estadual de Geoinformação. Banco de dados. Disponível em: <http://www.sieg.go.gov.br/>. Acesso em: 10 nov. 2016.

GUERRA, A. J. T. et al. Um estudo do meio físico com fins de aplicação ao planejamento do uso agrícola da terra no Sudoeste de Goiás. Rio de Janeiro: IBGE, DRNEA, 1989. (Projeto Cerrado II; Convênio IBGE/Embrapa).

GUIMARÃES, A. J. M.; ARAÚJO, G. M.; CORRÊA, G. F. Estrutura fitossociológica em área natural e antropizada de uma Vereda em Uberlândia, MG. Acta Botânica Brasilica, Belo Horizonte, v. 16, n. 3, p. 317-329, jul./set. 2002. Disponível em: <http://www.scielo.br/pdf/abb/v16n3/15397.pdf>. Acesso em: 06 nov. 2016.

LIMA, S. C.; QUEIROZ NETO, J. P. As Veredas e a evolução do relevo. Sociedade e Natureza, Uberlândia, v. 15, p. 481-488, 1996. 


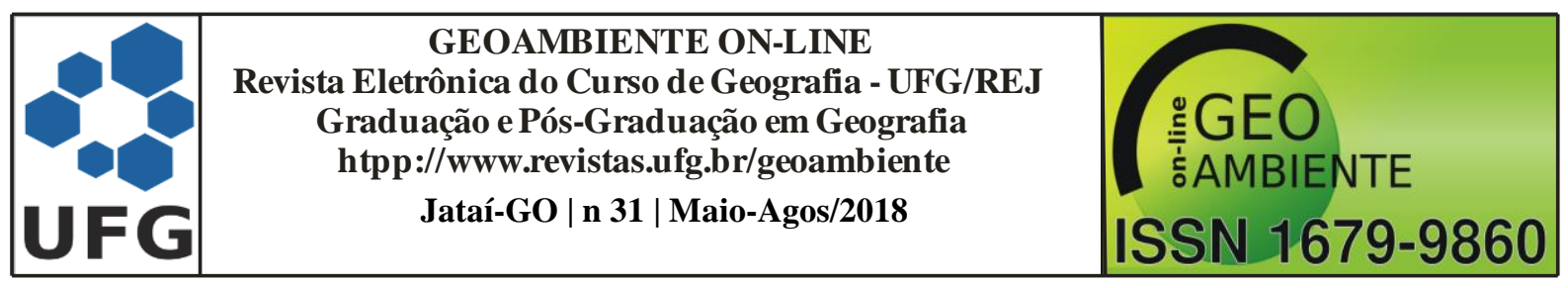

MELO, D. R.; ESPINDOLA, C. R. As Veredas nos planaltos de Buritizeiro/MG: estágio atual dos conhecimentos. In: SIMPÓSIO NACIONAL DE GEOMORFOLOGIA, 6., Goiânia. Anais... Goiânia, 2006. 1 CD-ROM.

MELO, D. R. Evolução das Veredas sob impactos ambientais nos geossistemas Planaltos de Buritizeiros/MG. 2008. 340 f. Tese (Doutorado em Geografia) - Instituto de Geociências, Universidade Federal de Minas Gerais, Belo Horizonte, 2008.

MENDONÇA, R. C. et al. Flora vascular do Cerrado. In: SANO, S. M.; ALMEIDA, S. P. (eds.). Cerrado: ambiente e flora. Planaltina: EMBRAPA Cerrados, 1998. p. 287-556.

MILCHUNAS, D. G., SALA, O. E.; LAUENROTH, W. K. A generalized model of the effects of grazing by large herbivores on grassland comunity structure. The American Naturalist, Chicago, v. 132, n. 1, p. 87-106, jul. 1988. Disponível em: <http://www.journals.uchicago.edu/doi/abs/10.1086/284839>. Acesso em 28 set. 2017.

MOREIRA, S. N. Flora, distribuição e estrutura da vegetação das áreas úmidas de uma região savânica brasileira: implicações para a conservação da biodiversidade. 2015. 131 f. Tese (Doutorado em Biologia Vegetal) - Departamento de Botânica do Instituto de Ciências Biológicas da Universidade Federal de Minas Gerais, Belo Horizonte, 2015.

; POTT, V. J.; POTT, A. Florística e fitossociologia de uma nascente de Vereda no município de terrenos, Mato Grosso do Sul, Brasil. In: CONGRESSO DE ECOLOGIA DO BRASIL, 9., 2009, São Lourenço, MG. Anais... São Lourenço, MG, 2009.

OLIVEIRA, G. C. Perfil florístico e distribuição das espécies vegetais, em relação ao gradiente de umidade do solo, em seis veredas no Triângulo Mineiro. 2005. 67 f. Dissertação (Mestrado em Ciências Biológicas) - Universidade Federal de Uberlândia, Uberlândia, 2005.

PASSOS, I. M. et al. Caracterização fisico-quimica de amostras de solo em áreas de cerrado e de vereda, na região do rio Catulé em Bonito de Minas-MG.Unisanta BioScience, Santos, SP, V. 4, n. 1, p. 38-47, 2015.

PEREIRA, B. A. S. et al. Levantamento florístico da área de proteção ambiental (APA) da bacia do rio São Bartolomeu, Distrito Federal. In: OLIVEIRA, R. J. M. (ed.). Congresso Brasileiro de Botânica, 36., 1985, Curitiba, Anais...Curitiba: UFPR, 1985. p. 419-492.

PEREIRA, E. et al. Evolução das sinéclises paleozoicas: províncias Solimões, Amazonas, Parnaíba e Paraná. In: HASUI, Y. et al. (Org.). Geologia do Brasil. São Paulo: Beca, 2012. p. 374-394. 


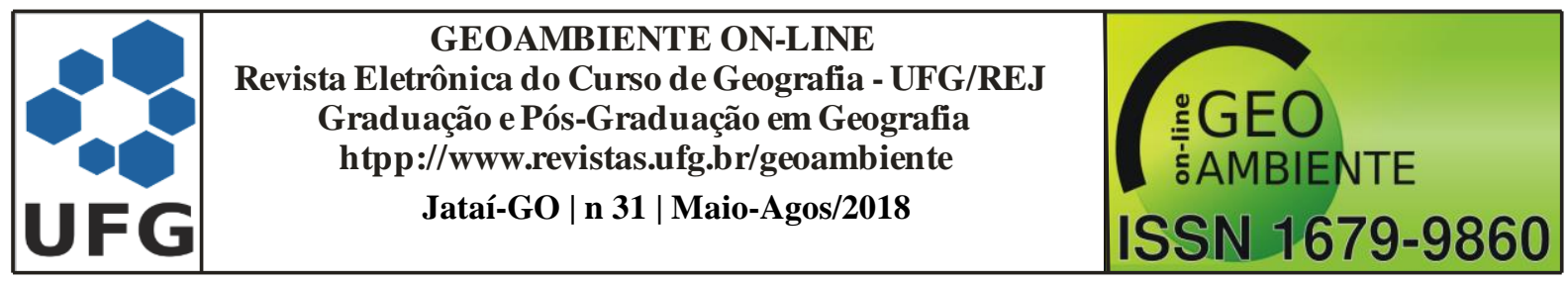

PINTO, J. R. R.; OLIVEIRA-FILHO, A. T.; HAY, J. D. V. Influence of soil and topography on the composition of a tree community in a central Brazilian valley forest. Edinburgh Journal of Botany, Edinburgh, v. 62, n.1/2, p. 69- 90, mar. 2005. Disponível em: <https://doi.org/10.1017/S0960428606000035>. Acesso em: 28 set. 2017.

RAMOS, M. V. V. Caracterização dos solos, da estrutura fitossociológica, e do estado nutricional da vegetação em Veredas de diferentes superfícies geomorfológicas do triângulo mineiro. Tese (Doutorado em Ecologia) - Universidade de Brasília, Brasília, 2004.

.et al. Veredas do Triangulo Mineiro: Solos, água e uso. Ciência Agrotécnica, Lavras, v. 30, n. 2, p. 283-293, mar/abr. 2006. Disponível em: <http://www.scielo.br/pdf/ cagro/v30n2/v30n2a14.pdf>. Acesso em: 28 set. 2017

.Veredas do Triângulo Mineiro: solos, água e uso. 2000. 127 f. Dissertação (Mestrado em Agronomia) - Universidade Federal de Lavras, Lavras, 2000.

REIS, A. T. C. C. Composição florística e estrutura da vegetação de Veredas do Cerrado no oeste da Bahia, Brasil. 2008. 92 f. (Mestrado em Botânica) - Universidade Estadual de Feira de Santana, Feira de Santana, 2008.

RESENDE, I. L. de M. Veredas da região central do Cerrado: ambientes, estrutura e composição florística. 2010. 61 f. Tese (Doutorado e Ciências Ambientais) - Universidade Federal de Goiás, Goiânia, 2010.

RIBEIRO, J. F. WALTER, B. M. T. Fitofisionomias do bioma Cerrado. In: SANO, S. M; ALMEIDA, S. P. RIBEIRO, J. F. Cerrado: ambiente e flora. Brasília: Embrapa Cerrados, 2008. p 89-166.

SANTOS, R. D. dos et al. Manual de descrição e coleta de solo no campo.6. ed. rev. ampl. Viçosa, MG: Sociedade Brasileira de Ciência do Solo, 2013 a.

SANTOS, E. V. dos et al. Visão ambiental do subsistema Vereda na microrregião de Catalão (GO). Espaço em Revista, Catalão, v. 15, n. 2, p. 141-162, jul./dez. 2013b. Disponível em: <https://www.revistas.ufg.br/espaco/article/view/28071/15902>. Acesso em: 05 nov. 2016.

SILVA, M. P. et al. Levantamento fitossociológico em ambiente de vereda na APP ribeirões do Gama e Cabeça de Veado, Brasília-DF. Revista Eletrônica Geoaraguaia, Barra do Garças, v. 6, n. 1, p. 84-98, jan./jul. 2016. Disponível em: <revistas.cua.ufmt.br/geoaraguaia/index.php/geo/article/download/152/>. Acesso em: 27 set. 2017. SOUZA, V. C.; LORENZI, H. Botânica sistemática:guia ilustrado para identificação das famílias de Angiospermas da flora brasileira, baseado em APG II. Nova Odessa: Instituto Plantarum, 2005. 


\begin{tabular}{|c|c|c|}
\hline & $\begin{array}{c}\text { GEOAMBIENTE ON-LINE } \\
\text { Revista Eletrônica do Curso de Geografia - UFG/REJ } \\
\text { Graduação e Pós-Graduação em Geografia } \\
\text { htpp://www.revistas.ufg.br/geoambiente } \\
\text { Jataí-Go | n 31 | Maio-Agos/2018 }\end{array}$ & $\begin{array}{c}\text { GEO } \\
\text { G }\end{array}$ \\
\hline \multirow{2}{*}{ GMBIENTE } \\
ISSN 1679-9860
\end{tabular}

TEIXEIRA, G. de P. Reconhecimento geológico de Rio Verde ao Araguaya, Estado de Goiáz.

Boletim do Serviço Geológico e Mineralógico, Rio de Janeiro, v. 59, p. 1-34, mar. 1932. 